\title{
GERAKAN DAKWAH PEMBAHARUAN: DARI SURAU JEMBATAN BESI SAMPAI SUMATRA THAWALIB PADANG PANJANG
}

\author{
Dedy Pradesa \\ STID Al-Hadid, Surabaya \\ depra19312@gmail.com
}

\author{
Siti Umayatun \\ Alumni Pascasarjana UIN \\ Sunan Kalijaga, Yogyakarta
}

\author{
M. Abdul Aziz \\ STIE-SBI, Yogyakarta \\ azizannawawi@gmail.com
}

\begin{abstract}
Abstrak: Pembaharuan Islam di Minangkabau awal abad ke-20 M melalui Surau Jembatan Besi atau Sumatra Thawalib Padang Panjang menunjukkan hasil yang lebih nyata dari pada Kaum Padri pendahulunya. Oleh karenanya penting untuk dikaji sebagai pelajaran bagi aktivis dakwah untuk melanjutkan upaya pembaharuan, mengingat potret sebagian umat Islam Indonesia yang tertinggal, jumud, menolak ilmu pengetahuan modern, dan lain-lain kerap dijumpai. Fokus masalah studi ini adalah gerakan dakwah pembaharuan dari Surau Jembatan Besi sampai Sumatra Thawalib Padang Panjang, sehingga melihatnya dalam perspektif sebagai institusi dakwah. Tujuan studi ini untuk memahami lebih jauh gerakan dakwah pembaharuan yang dilakukan. Metodologi studi kualitatif pustaka historis, dengan sumber data laporan penelitian dan studi terkait. Analisis data secara kualitatif historiografis, dipandu konsep gerakan dakwah pembaharuan. Hasil studi menunjukkan bahwa fenomena gerakan dakwah pembaharuan dari Surau Jembatan Besi sampai Perguruan Sumatra Thawalib Padang Panjang memiliki beberapa kekhasan, yaitu: pemanfaatan pranata sosial "surau" sebagai basis pembentukan pergerakan; latar belakang dan visi dakwah pembaharuan yang terkait penyakit masyarakat muslim Minangkabau; pola hubungan antara subjek dan mitra dakwah, mitra dakwah dibina dan diorganisir menjadi kader pembaharu; pesan dakwah pembaharuan untuk menjawab masalah terkait adat, tarekat, dan syariat; pengembangan metode dan media dakwah baru; efek dakwah yang menimbulkan pro dan kontra.
\end{abstract}

Kata kunci: gerakan dakwah pembaharuan, Surau Jembatan Besi, Sumatra Thawalib

\begin{abstract}
Reform of Islam in Minangkabau in the early 20th century through Surau Jembatan Besi or Sumatra Thawalib Padang Panjang indicates more obvious results than its predecessor, Kaum Padri. Therefore, it is essential to study this matter for $d a^{\prime}$ wah activists so they can continue the efforts of reform, considering Moslems in Indonesia who are left behind, obstinate, refusing modern sciences, etc. can be frequently encountered. The focus on this study is the movement of reform da'wah from Surau Jembatan Besi to Sumatra Thawalib Padang Panjang. Therefore, it is necessary to see in the perspective of da'wah institution. It aims to understand more about the movement of reform da'wah conducted. The study method used is qualitative by historical literature, with data sources from related research report and study. Data analysis used is historiographic qualitative, guided with the concept of the movement of reform da' wah. The study indicates that the phenomenon of the movement of reform da'wah from Surau Jembatan Besi to the institution of Sumatra Thawalib Padang Panjang has several typical characteristics, i.e.: utilization of social institution "surau (small mosque)" as a base of initializing a movement; background and vision of reform da'wah which are related to the social disorders of Minangkabau's society of Moslems; pattern of relationship between subject and partners of da'wah, the partners of da'wah were developed and organized to be reform cadres; messages of reform da'wah to solve problems related to custom,
\end{abstract}


tarekah, and syariah (Islamic law); method development and new da'wah media; effects od da'wah which emerges pro and cons.

Keywords: movement of reform da'wah, Surau Jembatan Besi, Sumatra Thawalib

\section{Pendahuluan}

Pembaharuan Islam atau modernisme Islam mengandung arti pemikiran dan gerakan untuk menyesuaikan paham-paham keagamaan Islam dengan perkembangan baru yang ditimbulkan oleh ilmu pengetahuan dan teknologi modern agar Islam terlepas dari kemunduran dan seterusnya dibawa kepada kemajuan. ${ }^{1}$ Dalam konteks Indonesia, wacana pembaharuan Islam gencar dilakukan mulai awal abad ke-20 Masehi (M), yaitu pada masa kolonialisme Hindia Belanda, yang ditunjukkan dengan lahirnya berbagai organisasi Islam baik yang bersifat sosial, politik, pendidikan, atau murni keagamaan. ${ }^{2}$ Rahman menjelaskan bahwa daerah Minangkabau, Sumatra Barat, dapat dianggap sebagai salah satu titik awal masuknya ide-ide modern ke Nusantara. Kontak antara Minangkabau dengan dunia Arab terjalin terutama melalui media haji, namun kemudian melebar menjadi kontakkontak intelektual yang lebih permanen. Ini dimungkinkan antara lain oleh adanya perbaikan ekonomi di daerah ini sebagai hasil langsung dari internasionalisasi perdagangan kopi dan hasil-hasil bumi lainnya. Ringkasnya, dinamisme daerah ini yang sedemikian menonjol telah

\footnotetext{
${ }^{1}$ Harun Nasution, Pembaharuan Dalam Islam Sejarah Pemikiran dan Gerakan, (Jakarta: Bulan Bintang, 1992), 11.

2 Zumrotin, "Modernisme Islam dan Implikasinya terhadap Kehidupan Politik Umat Islam di Indonesia pada Paruh Pertama Abad ke-XX M," (Skripsi, IAIN Sunan Ampel, Surabaya, 1996), 2.
}

membuatnya lebih dahulu merasakan modernisasi dalam banyak hal. ${ }^{3}$

Umumnya masyarakat Minangkabau telah merata memeluk agama Islam pada abad ke-18 M. Meskipun demikian, masih dijumpai beberapa praktik adat yang bertentangan dengan ajaran agama. Fenomena ini dapat dilihat dengan masih banyak praktik ibadah yang berbaur dengan adat dan kepercayaan tradisional yang tetap mereka pertahankan. Persoalanpersoalan yang sering dilakukan dan bertentangan dengan agama Islam di antaranya judi, sabung ayam, mengisap madat, hukum waris adat matrilineal (garis keturunan (bu), ${ }^{4}$ serta pelaksanaan ajaran tarekat yang bertentangan dengan ajaran Islam. Realitas pelaksanaan ajaran Islam yang demikian, meresahkan beberapa kalangan ulama, terutama ketika sepulangnya tiga orang haji dari Mekkah yaitu Haji Miskin Padai Sikat, Haji Abdurrahman Piobang, dan Haji Muhammad Arif Lintau. Mereka kemudian melakukan gerakan pembaharuan di Minangkabau, sehingga agak berbeda dengan gejala umum pembaharuan di Nusantara, pembaharuan Islam di Minangkabau telah dimulai sejak abad ke19 M. Semangat pembaharuan mereka bersifat radikal sehingga menimbulkan

\footnotetext{
${ }^{3}$ Rini Rahman, "Modernisasi Pendidikan Islam Awal Abad 20 Studi Kasus di Sumatera Barat," Jurnal Humanus, Volume XIV Nomor 02 (2015): 175.

4 Hamka, Islam dan Adat Minangkabau, (Jakarta: Pustaka Panjimas, 1985), 106.
} 
konfrontasi dan konflik dengan pihak kaum Adat. Konfrontasi tersebut berujung terjadinya Perang Padri tahun 1821-1837 M. Dalam perang ini di dalamnya juga ada campur tangan pihak Belanda untuk mengadu domba dan mengambil keuntungan. Belanda mempropagandakan bahwa Perang Padri adalah perang hitam putih, pertentangan antara Kaum Agama dan Kaum Adat. ${ }^{5}$ Meskipun dalam Perang Padri, ulama-ulama pembaharu kalah dan tersisihkan, namun usaha pembaharuan sama sekali tidak terhenti.

Perjuangan pembaharuan tersebut dilanjutkan oleh anak-anak dan pewarispewaris Padri yang menempuh pendidikan agama di Mekah dan Timur Tengah. Di bawah kepeloporan dua tokoh pewaris Padri, yaitu Syekh Ahmad Khatib AlMinangkabaui dan Syekh Thaher Jalaluddin Al-Azhari. Pembaruan Islam di Minangkabau awal abad ke-20 M dimulai ketika murid-murid Syekh Ahmad Khatib, di antaranya adalah Haji Abdullah Ahmad dan Haji Abdul Karim Amrullah pulang ke kampung halamannya dan membawa paham-paham pembaharuan. Mereka mengajar di surau-sura kecil untuk dakwah dan pengajaran agama di masyarakat. Gerakan pembaharuan di Minangkabau memang lebih banyak terpusatkan pada lokasi-lokasi surau yang telah berkembang dengan baik. Dari para pengajar muda inilah usaha pembaharuan Islam dilahirkan, bukan hanya terkait pembaharuan dalam bidang hukum adat, tarekat, dan syariat, namun juga modernisasi kegiatan dakwah dan pengajaran Islam, khususnya berkaitan

5 Ibid., 105.

${ }^{6}$ Burhanuddin Daya, Gerakan Pembaruan Pemikiran Islam: Kasus Sumatra Thawalib, (Yogyakarta: Tiara Wacana, 1990), 64. dengan surau sebagai lembaga pendidikan Islam. ${ }^{6}$ Salah satu surau yang maju dan akhirnya menjadi pembangkit semangat dalam jalur dakwah dan pendidikan adalah Surau Jembatan Besi di Padang Panjang yang dalam perkembangan berubah menjadi Perguruan Sumatra Thawalib. ${ }^{7}$ Secara keseluruhan pembaharuan pemikiran Islam di Minangkabau pada abad ke-20 yang salah satunya dilakukan melalui pengembangan surau ke dalam institusi perguruan seperti Sumatra Thawalib Padang Panjang dapat terus terlaksana secara bertahap dan diterima secara luas oleh masyarakat muslim Minangkabau.

Kajian mengenai gerakan pembaharuan Islam di Minangkabau (Sumatra Barat) telah banyak dilakukan, baik yang secara umum maupun spesifik membahas Sumatra Thawalib, di antaranya adalah: (1) Gerakan Pembaharuan Pemikiran Islam Kasus Sumatra Thawalib karya Burhanuddin Daya yang mendeskripsikan latar belakang, tujuan, dan program Sumatra Thawalib, pemikiran dan sepak terjangnya dalam menghadapi kenyataan adat, tarekat, dan syariat yang berkembang di masyarakat, perkembangan Sumatra Thawalib menjadi organisasi sosial politik, hingga kemunduran Sumatra Thawalib. ${ }^{8}$ Karya tersebut memberikan ulasan yang cukup menyeluruh mengenai Sumatra Thawalib, khususnya terkait perannya dalam pembaharuan pemikiran lewat kegiatan pendidikan dan sosial politik; (2) School and Politics, The Kaum Muda Movement in West

\footnotetext{
7 Ibid., 68.

${ }^{8}$ Daya, Gerakan Pembaharuan., 16.
} 
Sumatra 1927-1933 karya Taufik Abdullah, ${ }^{9}$ yang menjelaskan kegiatan dan perkembangan Sumatra Thawalib dengan aktivitas politik dalam hal ini melawan kolonialisme sampai dengan tahun 1933-an; (3) Disertasi dari Fachri Syamsuddin yang berjudul Pembaharuan Islam di Minangkabau Awal Abad XX: Studi terhadap Pemikiran Syekh Muhammad Jamil Jambek, Syekh Abdullah Ahmad, dan Syekh Abdul Karim Amrullah. Dalam desertasi tersebut lebih menyoroti pada aspek pemikiran ketiga tokoh pembaharu abad ke-20 M di Minangkabau tersebut terkait pembaharuan pemikiran dalam bidang adat, tarekat, dan syariat, sehingga tidak secara khusus membahas Surau Jembatan Besi atau Sumatra Thawalib. Salah satu temuannya adalah keberadaan lembaga pengajaran/pendidikan Islam (seperti Sumatra Thawalib) menjadi pemikiran kunci sebagai dasar keberhasilan aktivitas/usaha pembaharuan di masyarakat Minangkabau; ${ }^{10}$ (4) Artikel dalam Indonesian Journal of Islam and Muslim Societies (IJIMS) yang berjudul Model of Strategies in Developing Islamic Thought Through Curriculum: A Study of Sumatra Thawalib 1900-1942, karya Muh. Saerozi. Makalah tersebut menjelaskan model strategi untuk mengembangkan pemikiran Islam melalui kurikulum yang dikembangkan oleh Sumatra Thawalib sebagai Institusi Pendidikan. Hasilnya menunjukkan bahwa strategi pengembangan kurikulum Sumatra Thawalib dalam pemikiran Islam tidak selalu

\footnotetext{
9 Taufik Abdullah, School and Politics, The Kaum Muda Movement in West Sumatera 1927-1933, (New York: Cornell University, 1971).

10 Fachri Syamsuddin, "Pembaharuan Islam di Minangkabau Awal Abad XX: Studi terhadap Pemikiran Syekh Muhammad Jamil Jambek, Syekh
}

membatalkan karya ulama klasik. Namun, pikiran itu justru membuat mereka menghargai dan berpendapat bahwa karyakarya ulama klasik dapat dijadikan sebagai pedoman pemikiran siswa agar menjadi lebih rasional dan dinamis. ${ }^{11}$

Berdasarkan kajian terhadap studi-studi terdahulu di atas, diketahui bahwa studi terhadap pembaharuan Islam di Minangkabau dengan fokus Surau Jembatan Besi atau Sumatra Thawalib, lebih banyak melihatnya dalam perspektif sebagai institusi pendidikan Islam yang menjadi salah satu hasil pembaharuan sekaligus kunci utama dalam keberhasilan pembaharuan pemikiran Islam di Minangkabau. Studi lainnya melihat Sumatra Thawalib dalam perspektif sebagai institusi sosial politik, yang melakukan gerakan-gerakan sosial untuk pembaharuan pemikiran Islam serta aktivitas politik untuk melawan kolonialisme Belanda atau menentang beberapa kebijakan pemerintahan Hindia Belanda. Untuk itu studi ini akan mengkaji dalam perspektif yang berbeda, yaitu dalam konteks sebagai institusi dakwah atau yang melakukan gerakan dakwah dalam proses pembaharuan Islam di Minangkabau. Dalam konteks tersebut, terdapat beberapa asumsi yang perlu diperjelas agar studi ini bisa dilanjutkan. Pertama, kaitan antara konsep dakwah dan pembaharuan Islam. Pembaharuan Islam merupakan usaha untuk memperbarui situasi sosial masyarakat Islam dan menyesuaikannya

Abdullah Ahmad, dan Syekh Abdul Karim Amrullah," (Disertasi, IAIN Sunan Kalijaga, Yogyakarta, 2004), xiii. 11 Muh. Saerozi, "Model of Strategies in Developing Islamic Thought Through Curriculum: A Study of Sumatra Thawalib 1900-1942," Indonesian Journal of Islam and Muslim Societies (IJIMS) Volume 4, Number 2, (December 2014): 233-234. 
dengan nilai-nilai tertentu atau perkembangan ilmu pengetahuan dan teknologi modern. Sementara dakwah secara filosofis bukan hanya kegiatan mengajak orang lain pada kebaikan (ajaran Islam), namun dakwah juga merupakan upaya rekayasa sosial, khususnya dalam konteks masyarakat yang dikuasai tirani baik yang mengatasnamakan kekuasaan, agama, hukum adat, dan sebagainya sehingga dengan dakwah bertujuan untuk melakukan pembebasan sosial dari tirani tersebut. ${ }^{12}$ Salah satu esensi dari kegiatan dakwah adalah adanya proses perubahan dan peningkatan kualitas hidup dan kehidupan masyarakat, sehingga dakwah merupakan upaya reformasi dan pembaharuan (tajdid). ${ }^{13}$ Oleh karenanya dalam gerakan atau proses pembaharuan Islam di masyarakat selalu melibatkan kegiatan dakwah di dalamnya. Maka demikian pula dalam pembaharuan Islam di Minangkabau juga tidak terlepas dari kegiatan dakwah.

Kedua, konteks Surau Jembatan Besi dan Perguruan Sumatra Thawalib Padang Panjang sebagai institusi dakwah. Surau sebagai salah satu institusi sosial di masyarakat Minangkabau telah lama ada sejak sebelum Islam masuk. Azyumardi Azra mengatakan bahwa dalam perkembangan selanjutnya surau semakin luas fungsinya. Selain menjadi semacam asrama anak-anak muda, juga menjadi tempat mengaji, belajar agama, tempat upacara-upacara yang berkaitan dengan agama, tempat suluk, tempat berkumpul dan rapat, tempat

12 A. llyas Ismail dan Prio Hotman, Filsafat Dakwah Rekayasa Membangun Agama dan Peradaban Islam, (Jakarta: Kencana, 2011), 61-62, 71.

13 Asep Muhiddin, Dakwah dalam Perspektif AlQuran, (Bandung: Pustaka Setia, 2002), 36. penginapan musafir, tempat berkasidah/bergambus dan sebagainya. ${ }^{14}$ Sehingga surau memiliki fungsi sosial yang luas, di dalamnya mencakup kegiatan ibadah/keagamaan, dakwah, pendidikan Islam, pergaulan sosial, serta sistem informasi sosial. Dalam proses transformasi surau sebagai lembaga pendidikan modern dalam bentuk perguruan seperti Sumatra Thawalib Padang Panjang secara fungsi sosial sebenarnya lebih difokuskan dalam bidang pendidikan. Namun dalam kenyataannya, sebagai bagian dari usaha pembaharuan juga dilakukan kegiatankegiatan yang bersifat dakwah, bahkan perkembangan lebih lanjut merambah ke aktivitas sosial politik. Oleh karenanya mengkaji surau dan Sumatra Thawalib dalam konteks sebagai institusi yang melaksanakan kegiatan dakwah relevan dilaksanakan.

Terdapat beberapa nilai penting dari perlunya studi terhadap gerakan dakwah Surau Jembatan Besi atau Sumatra Thawalib Padang Panjang dalam proses pembaharuan Islam di Minangkabau, yaitu, pertama, pembaharuan Islam di Minangkabau pada abad ke-20 M yang salah satunya dipelopori $H$. Abdul Karim Amrullah selaku pimpinan Surau Jembatan Besi dan Sumatra Thawalib Padang Panjang menunjukkan hasil yang lebih nyata, dari pada pembaharuan yang dilakukan oleh pendahulunya (kaum Padri). Hal tersebut tidak terlepas dari pendekatan yang dilakukan dalam proses pembaharuan Islam, yang tidak menggunakan jalan-jalan

\footnotetext{
${ }^{14}$ Azyumardi Azra, "Surau di Tengah Krisis: Pesantren dalam Perspektif Masyarakat" dalam Dawam Rahardjo, Pergulatan Dunia Pesantren Membangun dari Bawah, (Jakarta: P2M, 1985), 157.
} 
radikal, kekerasan, dan pemaksaan, tetapi melewati jalan-jalan dakwah dan pendidikan yang mengedepankan rasionalitas dan sikap kritis terhadap berbagai praktik keagamaan yang diindikasi bertentangan dengan Islam yang telah berkembang di masyarakat. Kedua, pada kenyataannya proses pembaharuan Islam di Indonesia masih perlu untuk terus dilakukan, sebab pemahaman ajaran Islam di beberapa tempat di Indonesia masih banyak tercampur atau dipengaruhi nilainilai anismime-dinamisme dan ajaran Hindu Buddha, sehingga melahirkan pengamalan yang bertentangan dengan Alquran dan Sunah. Potret sebagian umat Islam Indonesia yang jumud, tertinggal, dan menolak ilmu pengetahuan modern masih banyak dijumpai. Belum lagi fenomena umat Islam yang tekstual dan skripturalis dalam memahami teks Alquran dan Sunah, akibatnya mereka terjebak menjadi radikal dan tidak memahami substansi ajaran Islam. Oleh karenanya, pembaharuan Islam di Indonesia sejatinya belum selesai, usahausaha tersebut perlu untuk terus dilanjutkan. Dalam konteks itulah, mengkaji pembaharuan Islam di Minangkabau sebagai suatu pelajaran dan inspirasi bagi umat Islam Indonesia hari ini penting untuk dilaksanakan. Ketiga, upaya pembaharuan Islam tidak terlepas dari kegiatan dakwah. Dari segi keilmuan dakwah, kajian terhadap gerakan dakwah dalam proses pembaharuan Islam di Minangkabau dapat memperkaya khazanah keilmuan dakwah khususnya terkait dinamika gerakan dakwah dalam berinteraksi dengan struktur sosial tertentu seperti dalam adat istiadat Minangkabau. Hal ini juga penting sebagai pijakan pelajaran bagi kegiatan dakwah yang berorientasi pembaharuan Islam di daerah selainnya.
Fokus masalah dalam studi ini adalah gerakan dakwah yang dilakukan oleh para ulama pembaharu Surau Jembatan Besi kepada masyarakat muslim Minangkabau, sehingga aktivitas yang dikaji dibatasi pada aspek dakwahnya, dengan kata lain mengkaji fenomena tersebut dalam perspektif sebagai institusi dakwah. Mengingat Surau Jembatan Besi yang dalam perkembangan selanjutnya terinstitusionalisasi menjadi lembaga sosial pendidikan, maka batasan yang dikaji pada studi ini adalah pada masa Surau Jembatan Besi dan masa awal-awal Perguruan Sumatra Thawalib Padang Panjang, dimana aktivitas dakwah masih cukup dominan ketika itu. Masa perkembangan selanjutnya tidak menjadi fokus kajian. Pertanyaan pokok yang hendak dijawab adalah apa, mengapa, dan bagaimana gerakan dakwah pembaharuan yang di Minangkabau pada awal abad ke-20 M dalam kasus Surau Jembatan Besi atau Sumatra Thawalib Padang Panjang? Apa dan mengapa terkait latar belakang dan tujuan atau visi dakwah pembaharuannya, sedangkan aspek bagaimana terkait subjek, objek, materi, metode, dan media yang digunakan dalam gerakan dakwah pembaharuan kasus Surau Jembatan Besi atau Sumatra Thawalib. Sehingga tujuan dari studi ini adalah untuk mendeskripsikan dan memahami lebih jauh gerakan dakwah Surau Jembatan Besi atau Sumatra Thawalib dalam proses pembaharuan di masyarakat Minangkabau. Dasar teoritis yang digunakan adalah konsep gerakan dakwah pembaharuan. Relevansi konsep gerakan dakwah adalah karena realitas yang dikaji adalah fenomena yang identik dengan gerakan dakwah yang memiliki ciri adanya pergerakan dan institusionalisasi menjadi organisasi 
dakwah. Sedangkan konsep pembaharuan terkait konteks makro gerakan dakwah yang dilakukan dalam rangka pembaharuan Islam di Minangkabau awal abad ke-20 M.

Secara metodologi, menggunakan pendekatan kualitatif pustaka historis. Kualitatif karena tujuan dari studi ini adalah untuk memahami suatu realitas pada setting sosial tertentu, dalam hal ini adalah situasi sosial pembaharuan Islam di masyarakat Minangkabau pada awal abad ke-20 M. Pendekatan pustaka karena proses pengumpulan data dalam studi ini menggunakan sumber-sumber kepustakaan yang dipandang relevan, yaitu terkait data tentang aktivitas, tempat dan orang-orang yang terlibat dalam gerakan dakwah melalui Surau Jembatan Besi sebagai bagian dari proses pembaharuan Islam di Minangkabau. Pendekatan historis karena studi ini mengkaji peristiwa yang terjadi di masa lampau, yaitu pada awal abad ke-20 M, kurang lebih antara tahun 1900-1925, yang coba direkonstruksi berdasarkan temuan data pada sumber-sumber kepustakaan yang digunakan. Adapun kepustakaan yang menjadi sumber data dalam studi ini adalah: (1) Gerakan Pembaharuan Pemikiran Islam Kasus Sumatra Thawalib karya Burhanuddin Daya; (2) Ayahku; dan (3) Islam dan Adat Minangkabau, keduanya karya Haji Abdul Malik Karim Amrullah (Hamka); ${ }^{15}$ (4) Gerakan Modern Islam di Indonesia 19001942, karya Deliar Noer; (5) Pembaharuan Islam di Minangkabau Awal Abad XX: Studi terhadap Pemikiran Syekh Muhammad

15 Hamka adalah putra dari Syekh Abdul Karim Amrullah (Tokoh pembaharu, pimpinan dan pengajar Surau Jembatan Besi dan Sumatera Thawalib Padang Panjang)
Jamil Jambek, Syekh Abdullah Ahmad, dan Syekh Abdul Karim Amrullah, disertasi karya Fachri Syamsuddin; (6) Thawalib Padang Panjang dan Pembaharuan Pendidikan Islam, thesiskarya Dt. R. Endah Hamidin. Selain itu juga digunakan beberapa artikel jurnal dan laporan hasil penelitian lainnya yang terkait. Analisis data kualitatif dilakukan secara interaktif, sesuai dengan model Miles dan Huberman, yaitu mulai reduksi data (pemilahan data), penyajian data dan penarikan kesimpulan. ${ }^{16}$ Proses pemilahan dan penyajian data disusun secara historiografis berdasarkan temuan data kepustakaan, sehingga akan menghasilkan satu narasi gerakan dakwah sejak awal proses pembaharuan masa Surau Jembatan Besi hingga menjadi perguruan Thawalib dan perkembangannya. Interpretasi data dan penarikan kesimpulan dipandu konsep gerakan dakwah pembaharuan.

\section{Gerakan Dakwah Pembaharuan}

Gerakan artinya adalah perbuatan, kegiatan, aktivitas atau keadaan bergerak. ${ }^{17}$ Gerakan dakwah secara umum diartikan setiap aktivitas dalam rangka melaksanakan dakwah Islam. ${ }^{18}$ Namun yang dimaksud gerakan dakwah dalam studi ini adalah salah satu model atau paradigma dalam kegiatan dakwah, sehingga gerakan dakwah diartikan sebagai dakwah yang lebih menekankan pada perbuatan/tindakan, aksi, atau aktivitas nyata, ketimbang memberikan wacana-wacana yang bersifat

\footnotetext{
16 Ismail Nawawi, Metode Penelitian Kualitatif, (Jakarta: Dwiputra Pustaka, 2012), 256-259.

17 Departemen Pendidikan Nasional, Kamus Besar Bahasa Indonesia, (Jakarta: Balai Pustaka, 2005), 356. 18 Ismail \& Hotman, Filsafat Dakwah., 233.
} 
teoritis, yang sering pula disebut sebagai gerakan Islam (alharakah al-islâmiyyah) atau jemaah dakwah/kelompok dakwah. Al-Qattani menjelaskan bahwa gerakan dakwah (harakah ad-da'wah) adalah suatu gerakan yang berorientasikan pada pengembangan masyarakat Islam dengan melakukan reformasi total (islah) terhadap seluruh aspek kehiduan sosial, baik terkait dengan individu (ishlâh al-fard), keluarga (ishlâh al-usrah), masyarakat (ishlâh almujtama'), dan negara (ishlâh aldaulah). ${ }^{19}$ Kekhasan model dakwah gerakan adalah pada latar belakang kemunculannya yang tidak hanya didasari nilai-nilai normatif perintah untuk berdakwah, tetapi juga ada faktor sosial dan historis utamanya fenomena kemunduran umat Islam. Tujuannya adalah adanya suatu pergerakan dari kondisi sebelumnya, perubahan untuk membawa umat kepada kehidupan yang lebih baik berlandaskan pada ajaran Islam. ${ }^{20}$ Pendekatan yang digunakan adalah dengan membentuk pendukung utama (jemaah inti). Mereka dibentuk dalam ikatan solidaritas keimanan dan memiliki tanggung jawab untuk pengembangan Islam dan lingkungannya, memperluas wilayah dan jaringannya sehingga dakwah dapat terus berkembang. Untuk itu jemaah mesti dibina dengan nilai-nilai ketauhidan, serta dididik supaya memiliki kualitas ibadah dan akhlak yang baik, serta terampil melakukan pengaturan atau pengorganisasian (tanzim) terhadap pergerakan dakwah. ${ }^{21}$

Sedangkan pembaharuan Islam berarti pemikiran dan gerakan umat Islam yang

\footnotetext{
${ }^{19}$ Ibid., 233.

20 lbid., 234-235.

${ }^{21}$ lbid., 239-240.

22 Nasution, Pembaharuan Dalam., 11.

${ }^{23}$ Ibid., 26.
}

timbul untuk menyesuaikan paham-paham keagamaan Islam dengan perkembangan baru yang ditimbulkan oleh ilmu pengetahuan dan teknologi modern agar Islam terlepas dari kemunduran dan seterusnya dibawa kepada kemajuan. ${ }^{22}$ Secara garis besar terdapat tiga gagasan pokok dalam pembaharuan Islam, yaitu: (a) kembali kepada Alquran dan Sunah sebagai sumber asli ajaran Islam; (b) pendapat ulama tidak merupakan sumber dan taklid kepada ulama tidak dibenarkan; (c) pintu ijtihad masih terbuka. ${ }^{23}$ Dalam konteks Indonesia, pembaharuan Islam berawal dari soal-soal ubudiyah yang berusaha memurnikan ajaran Islam dari pengaruh taqlid, bidah, dan khurafat dengan mengajak umat Islam kembali kepada Alquran dan Sunah. ${ }^{24}$ Mukti Ali menambahkan beberapa penyebab terjadinya pembaharuan Islam di Indonesia, yaitu: (a) ketidakbersihan dan campur aduknya kehidupan agama Islam, dalam arti praktik ajaran Islam dicampuradukkan dengan adat istiadat yang bertentangan dengan nilai-nilai Islam; (b) ketidakefisienan lembaga-lembaga pendidikan agama Islam; (c) aktivitas misi Katolik dan Protestan; (d) sikap acuh tak acuh, malah kadang-kadang merendahkan dai pada golongan intelegensia terhadap Islam; (e) keadaan politik, ekonomi, dan sosial umat Islam yang terpuruk, sebagai akibat keadaan Indonesia sebagai negeri jajahan. ${ }^{25}$

Pembaharuan Islam menjadi salah satu tujuan dalam gerakan dakwah. Sementara dakwah atau gerakan dakwah hanyalah

\footnotetext{
24 Deliar Noer, Gerakan Modern Islam di Indonesia 1900-1942, (Jakarta: LP3ES, 1996), 8.

${ }^{25}$ A. Mukti Ali, Alam Pikiran Modern di Indonesia, (Yogyakarta: Yayasan Nida, 1971), 13.
} 
salah satu sarana untuk bisa melakukan pembaharuan Islam, khususnya apabila pembaharuan tersebut terkait pemikiran dan nilai-nilai ajaran Islam. Dengan demikian gerakan dakwah pembaharuan yang dimaksud dalam studi ini adalah proses perbaikan dan pemecahan masalah umat yang dilakukan melalui pergerakan, yaitu pembentukan, pembinaan, dan pengorganisasian kelompok (jemaah), dalam rangka mengubah kehidupan umat Islam menjadi lebih baik. Kekhasan gerakan dakwah pembaharuan adalah senantiasa dilatarbelakangi fenomena sosial masalah umat Islam, seperti masalah akidah yang tidak lagi menerapkan ajaran Islam dengan benar, mencampuradukkan dengan berbagai praktik adat istiadat yang bertentangan, serta kemunduran, kebodohan, dan ketertinggalan yang luar biasa khususnya dibandingkan dengan Barat. Oleh karenanya visi atau tujuan gerakan dakwah pembaharuan adalah untuk memperbaiki dan memajukan umat Islam dengan mengembalikan sesuai tuntutan Alquran dan Sunah.

Sebagai sebuah aktivitas dakwah maka gerakan dakwah pembaharuan juga tidak terlepas dari unsur-unsur dakwah, yaitu adanya pendakwah, mitra dakwah, pesan dakwah, metode dakwah, media dakwah, dan efek dakwah. ${ }^{26}$ Karakteristiknya yang dilakukan melalui pergerakan mengakibatkan subjek atau pendakwah yang terlibat tidaklah tunggal, tetapi ada kelompok, sekalipun ada satu atau beberapa subjek yang memelopori, namun selalu terdapat proses pembentukan, pembinaan, dan pengorganisasian jemaah

${ }^{26}$ Ali Azis, Ilmu Dakwah Edisi Revisi, (Jakarta: Prenadamedia Grup, 2016), 64. (kelompok). Mitra dakwahnya lebih difokuskan pada umat Islam yang dipandang keliru secara akidah maupun amaliah, dari pada mereka yang belum memeluk Islam. Pesan dakwah ditekankan pada jawaban atas masalah-masalah sosial yang melatarbelakangi gerakan tersebut. Sangat dimungkinkan untuk melakukan perubahan-perubahan metode dan media dalam dakwahnya. Dari sisi efek dakwah selalu menimbulkan pro dan kontra sebagai implikasi dari tujuan dan pesan dakwah yang dibawa. Karakteristik-karakteristik itulah yang akan dianalisis lebih lanjut dalam gerakan dakwah pembaharuan Islam di Minangkabau pada kasus Surau Jembatan Besi yang kemudian berkembang menjadi Perguruan Sumatra Thawalib. Untuk itu sebelumnya akan dibahas konteks umum yang melingkupi kasus Surau Jembatan Besi atau Sumatra Thawalib, yaitu fenomena pembaharuan Islam di Minangkabau.

\section{Pembaharuan Islam di Minangkabau}

Sebelum masuknya Islam di Minangkabau, masyarakat Minangkabau merupakan komunitas yang taat dalam beragama dan kuat dalam memelihara dan memegang teguh nilai-nilai adat. Sebagaimana dikenal bahwa Minangkabau keras ke adat dan adat bersifat indak lapuk dik hujan, indak lakang dek panas. Hal tersebut terungkap dari pepatah "Biar mati anak, jangan mati adat". ${ }^{27}$ Dalam masyarakat minangkabau, ada tiga macam adat, yaitu adat istiadat, adat yang diadatkan, dan adat yang bersendi syara'. Nilai-nilai tersebut

27 Samsul Nizar, Memperbincangkan Dinamika Intelektual dan Pemikiran Hamka Tentang Pemikiran Islam (Jakarta: Kencana, 2007), 62-64. 
demikian mengkristal dan sangat mewarnai berbagai bentuk interaksi sosial serta pandangan hidup mereka. Ketika Islam masuk dan berkembang di Minangkabau, kehadiran Islam diterima dengan sangat terbuka. Masyarakat Minangkabau berusaha agar adat tetap bertahan dan relevan dari masa ke masa. Untuk itu perlu kompromistis dan keluwesan dalam mengembangkan diri untuk menerima proses pembaharuan. Hasil dari kompromistis dan keluwesannya itulah yang tidak selamanya cocok dengan ajaran Islam, sehingga konflik antara keduanya mudah terjadi. ${ }^{28}$

Fenomena tersebut dapat dilihat dengan banyaknya praktik ibadah Islam yang berbaur dengan adat dan kepercayaan tradisional yang tetap mereka pertahankan. Persoalan-persoalan yang sering dilakukan dan bertentangan dengan agama Islam diantara judi, sambung ayam, mengisap madat, mandi safar, hukum waris adat matrilineal, dan berbagai praktik tarekat yang menyimpang. ${ }^{29}$ Hamka menuturkan bahwa di Minangkabau saat itu perjalanan agama sudah sangat mundur. Tidak dapat dibedakan mana yang agama, mana yang perbuatan syirik. Bidah dan agama bercampur aduk. Selain itu juga hidup sihir yang sangat dimahirkan orang, azimat sebesar lengan digantung di pinggang seseorang, kadang-kadang guru agama menjadi tukang jual azimat. Makam-makam ulama dipandang keramat dijadikan tempat bernazar dan berniat. $^{30}$ Perbuatanperbuatan yang melanggar hukum Islam, kerusakan moral masyarakat, kejahatan yang berjangkit hampir di seluruh pelosok

\footnotetext{
28 Daya, Gerakan Pembaharuan., 51.

29 Hamka, Islam dan Adat Minangkabau (Jakarta: Pustaka Panjimas, 1985), 106.
}

negeri, tidak ada ulama yang berani turun tangan memperbaikinya, karena kewibawaan mereka sudah luntur dan mungkin juga mereka terlibat dalam suasana seperti itu. ${ }^{31}$ Keadaan itu terus berjalan melemahkan masyarakat, belum lagi pertentangan-pertentangan antar umat Islam karena perbedaan mazhab, tarekat, dan sebagainya yang semakin memperburuk kondisi dan memudahkan bagi bangsa asing untuk menguasai umat Islam.

Sebagaimana dijelaskan di awal, semangat pembaruan Islam di Minangkabau telah dimulai pada awal abad ke-19 M yang berlanjut dengan kekalahan para ulama pembaharu dalam Perang Padri, sehingga pembaharuan mengalami kemandegan. Keadaan umat Islam Minangkabau tidak jauh berbeda dengan masa-masa sebelumnya, bahkan lebih parah. Syamsuddin menegaskan bahwa di awal abad ke-20 M di Minangkabau terdapat beberapa keadaan yang menjadi pendorong terjadinya pembaharuan Islam, yaitu: (a) proses pencemaran Islam mencapai puncaknya, umat Islam sangat terikat pada ajaran tarekat yang menyuburkan takhayul, bidah dan khurafat; (b) ulama-ulama tanpa alasan yang jelas mudah saja mengharamkan orang Islam yang mengenakan pakaiannya orang-orang kafir; (c) berbagai unsur dari dalam dan luar negeri banyak yang masuk; (d) pemuka adat banyak yang mempunyai sikap yang berlebihan dalam mengagung-agungkan kekuasaan pemerintahan kolonial Belanda. $^{32}$

\footnotetext{
${ }^{30}$ Hamka, Ayahku, (Jakarta: Uminda, 1982), 70.

31 lbid., 101.

32 Syamsuddin, "Pembaharuan Islam.," 240.
} 
Empat murid Syekh Ahmad Khatib menjadi ulama-ulama muda pelopor pembaharuan di Minangkabau, yaitu, Syekh Muhammad Jamil Jambek dari Bukittinggi, Syekh Muhammad Thayib Umar dari Tanjung Dungayang, Syekh Abdullah Ahmad dari Padang Panjang, dan Syekh Abdul Karim Amrullah dari Maninjau. Merekalah yang kemudian dikenal dengan sebutan ulama Kaum Muda (Kaum Mudo). Daya menjelaskan bahwa Kaum Mudo patut dicatat sebagai kaum modernis, reformis, dan fundamentalis. Mereka hanya berpegang kepada Alquran dan Hadis sahih. Mereka berusaha menyucikan Islam dari segala unsur yang menodai tetapi menurut adat sudah dianggap sebagai bagian dari Islam, maka mereka menentang adat istiadat yang bertentangan dengan Islam dan segala amalan yang dianggap takhayul. Mereka mengutamakan rumusan-rumusan kembali tentang ajaran Islam secara rasional, yang kiranya lebih baik dan memungkinkan umat Islam untuk bersaing dalam dunia modern. Sementara sebagai antithesanya, muncullah istilah Kaum Tuo, yaitu golongan yang tidak setuju dengan paham Kaum Mudo, sebab pada dasarnya Kaum Tuo secara tradisional dianggap sebagai ulama yang hanya berperan dalam memegang pintu-pintu ke akhirat, yang mana Kaum Tuo sangat mengikatkan diri pada kekuasaan adat. $^{33}$ Kepincangan internal umat Islam Minangkabau antara kaum muda dengan kaum tua, yang pada dasarnya disebabkan perbedaan pandangan dalam bidang pendidikan dan mazhab yang mereka anut. Kaum muda umumnya lebih terpengaruh ide-ide pembaharuan yang saat itu tengah berkembang di Mesir. Sementara kaum tua mempertahankan kepercayaan tradisional mereka dalam masalah tasawuf, syariat, dan adat. Yang kemudian dipandang oleh kaum muda banyak mengandung khurafat, takhayul, bidah. Melihat fenomena pemahaman umat yang demikian, maka kaum muda berupaya secara keras melakukan serangkaian usaha untuk menyadarkan dan meluruskan pemahaman umat Islam kepada ajaran Islam yang kaffah, yang berdasarkan Alquran dan Sunah.

Surau menjadi elemen penting dalam proses pembaharuan di Minangkabau. Kaum Mudo memfokuskan pergerakannya pada lokasi dimana terdapat surau yang telah berkembang dengan baik. Melalui surau itulah gerakan pembaharuan berkembang luas, karena surau memiliki hubungan yang terbuka dengan masyarakat luas. Sebelumnya Kaum Muda tersebut merupakan tenaga pengajar di surau yang belajar di Mekkah dan kembali ke kampung halamannya lalu mengembangkan surau di wilayah mereka. Dari merekalah usaha pembaharuan Islam di lakukan. Sasarannya adalah pengembangan Islam yang murni, mengubah dan menyesuaikan hukum adat dengan hukum Islam dan mengobarkan semangat modern. Hal tersebut berarti mereka akan berhadapan dengan persoalan tarekat, adat, dan syariat yang telah berkembang sebelumnya di Minangkabau. Akibat gerakan itu memunculkan reaksi penentangan yang tidak dapat dihindarkan dari ulama Kaum Tuo. ${ }^{34}$

Berdasarkan uraian di atas dapat diketahui bahwa pembaharuan Islam di Minangkabau yang dipelopori oleh Kaum Mudo,

34 Ibid., 64-65. 
dilatarbelakangi oleh fenomena sosial kemunduran umat Islam Minangkabau. Saat itu terjadi penyakit atau kerusakan masyarakat, praktik-praktik kesyirikan, takhayul, bidah, ajaran tarekat yang bertentangan dengan Islam, taklid, dan kerusakan lainnya yang merajalela. Pada intinya hal-hal tersebut tidak sejalan dengan nilai-nilai dalam Alquran dan Hadis. Oleh karenanya perlu dilakukan pembaharuan dalam rangka mengembalikan praktik ajaran Islam di Minangkabau agar sesuai Alquran dan Hadis, memurnikan Tauhid, mendorong ijtihad dan kemajuan di berbagai bidang. Walhasil upaya pembaharuan ini memunculkan reaksi pertentangan dari ulama Kaum Tuo, khususnya dalam masalah tarekat, adat, dan syariat. Hal-hal itulah yang menjadi karakteristik umum pembaharuan Islam di Minangkabau pada awal abad ke-20 M. Pada konteks itulah Surau Jembatan Besi yang selanjutnya bertransformasi menjadi Perguruan Sumatra Thawalib hadir menjadi penggerak utama dalam gerakan dakwah pembaharuan di Minangkabau. Di bawah pengasuhan dua tokoh Kaum Mudo, Haji Abdullah Ahmad dan Haji Abdul Karim Amrullah, Surau Jembatan Besi menjadi wahana penyebarluasan ide-ide pembaharuan di Minangkabau. Sebelum menguraikan lebih jauh gerakan dakwah pembaharuan dari Surau Jembatan Besi sampai transformasinya menjadi Perguruan Sumatra Thawalib, akan diuraikan terlebih dahulu riwayat singkat Surau jembatan Besi sampai Perguruan Sumatra Thawalib.

\section{Dari Surau Jembatan Besi sampai Perguruan Sumatra Thawalib Padang Panjang.}

Surau Jembatan Besi di Padang Panjang, adalah awal pangkal sejarah Sumatra Thawalib, atau dahulunya Sumatra Thawalib adalah Surau Jembatan Besi. Haji M.D. Palimokayo pernah mengatakan bahwa pengajian di Surau Jembatan Besi telah berjalan sebelum tahun 1900 Tuangku (guru/pengasuh) yang pertama adalah Syekh Abdullah. Sistem yang dipakai sama dengan sistem pengajian yang terdapat pada surau-surau lainnya, yaitu sistem halaqah, para jemaah atau muridmurid melingkari gurunya. H. Abdullah Ahmad sekembalinya dari Mekkah tahun 1899 langsung mengajar di surau ini. Abdullah Ahmad melanjutkan tradisi pengajaran Islam di Surau Jembatan Besi dengan tetap mengikuti tradisi, tidak mengubah atau menambahinya. Dia dibantu oleh kakak beradik, Syekh Abdullatief dan Syekh Daud Rasyidi. Sewaktu Abdullah Ahmad meninggalkan Padang Panjang untuk mengembangkan sekolah di kota Padang, tanggung jawab Surau Jembatan Besi diserahkan kepada Syekh Daud Rasyidi. Syekh Daud Rasyidi bukan hanya mengajar orang mengaji, tetapi juga mengajar orang bermasyarakat dan memimpin jemaah, khususnya masyarakat Padang Panjang. Ketika dia berangkat ke Mekkah, pimpinan Surau Jembatan Besi diserahkan kepada Abdul Latief Rasyidi. ${ }^{35}$

Sementara Haji Abdul Karim Amrullah atau Haji Rasul pada mulanya mengajar mengaji di suraunya sendiri di Maninjau. Lalu dia diminta Abdullah Ahmad untuk membantu

35 Ibid., 81-82, 85. 
memajukan pengajian di Surau Jembatan Besi Padang Panjang. Dalam perkembangan, ketika Abdullah Ahmad sudah mulai berhasil membuka pendidikan yang diberi nama Adabiah School di Padang, dia meminta Haji Rasul untuk membantunya di Padang, dengan tetap mengajar ngaji pula di Surau Jembatan Besi. Sewaktu Abdul Latief Rasyidi meninggal dunia, seluruh jemaah Surau Jembatan Besi di Padang panjang meminta agar Haji Rasul menggantikannya dan menetap di Padang Panjang. Atas restu dari Abdullah Ahmad, permintaan masyarakat dikabulkan dan sejak tahun 1912, Haji Rasul menjadi pemimpin tunggal Surau Jembatan Besi. Setelah itu, bertambah ramailah Surau Jembatan Besi dan menjadi pusat pengajian besar di Minangkabau. Sejak itu pulalah para pedagang yang datang ke kota Padang Panjang mengaji dan dari Surau Jembatan Besi timbul gerakan pendorong kemajuan pendidikan, publikasi, tablig akbar dan perdebatan-perdebatan umum dengan para ulama Islam tradisional (Kaum Tuo) dan golongan adat. ${ }^{36}$

Dengan kedatangan Haji Abdullah Ahmad dan Haji Abdul Karim Amrullah ke surau ini, mulai ditekankan pentingnya 'ilm alat (penguasaan bahasa Arab dan berbagai cabangnya) dengan tujuan memungkinkan para siswa dan jemaah mempelajari sendiri buku-buku yang diperlukan, dan secara bertahap mengenal Islam dari sumbersumber utamanya, yaitu Alquran dan Hadis. Isi pengajian dan pembelajaran juga mulai dikembangkan, kepada murid-murid ditanamkan semangat baru seperti semangat berdiskusi, berpikir bebas, membaca, memahami, dan berkumpul atau

${ }^{36}$ Abdullah, School and Politics., 45.

37 Daya, Gerakan Pembaruan., 86. berorganisasi. Kitab-kitab mulai dibaca dan didiskusikan, serta para murid boleh bertanya dan mendebat. ${ }^{37}$ Adapun bahanbahan pelajaran yang digunakan adalah dengan dimasukkan kitab-kitab pelajaran dari Mesir sebagai mata pelajaran agama, serta mata pelajaran ilmu bumi dan sejarah. Untuk pelajar-pelajar pada tingkat tinggi, diajarkan kitab-kitab Abduh dan Rasyid Ridha, terutama Tafsir al-Manar. Selain itu juga kitab-kitab Taqi al-Din Ahmad Ibn Taimiyah yang "tidak tunduk" pada otoritas manapun dan sangat kritis mengecam bidah, pemujaan kepada wali-wali kramat, bai'at, dan ziarah ke tempat-tempat kramat. ${ }^{38}$

Mengenai organisasi, digagas oleh Haji Rasul untuk membentuk suatu organisasi yaitu perkumpulan

murid-murid dan guru-guru. Organisasi ini pada mulanya hanya merupakan perkumpulan semacam koperasi, dinamakan "Perkumpulan Sabun" karena organisasi ini berusaha memenuhi kebutuhan sehari-hari para pelajar, seperti sabun, pensil, dan lain-lainnya organisasi dengan nama Persaiyoan. Tujuan organisasi ini adalah untuk membantu memudahkan murid mendapatkan keperluan harian mereka dengan harga yang ringan dan longgar pembayaranya. ${ }^{39}$ Perkumpulan ini berjalan semakin pesat, keuntungan dari koperasi tersebut bisa membayar honor guru. Organisasi pelajar ini berubah nama menjadi Sumatra Thuwailib, kemudian berubah lagi dengan nama Sumatra Thawalib, setelah terjadi kesepakatan untuk menjadi satu organisasi antara Sumatra Thuwailib Surau Jembatan Besi dengan Sumatra Thuwailib Surau Parebek.

\footnotetext{
${ }^{38}$ Noer, Gerakan Modern., 56.

39 Ibid., 55.
} 
Organisasi inilah nantinya yang melahirkan perguruan Sumatra Thawalib Padang Panjang, setahap demi setahap mengadakan pembaharuan dalam bidang pendidikan, mengembangkan sistem pendidikan menjadi sistem persekolahan, membagi murid menjadi berkelas-kelas, mulai dari kelas satu, dan untuk tamat harus lulus kelas tujuh. ${ }^{40}$

Selain merubah cara pembelajaran di Surau Jembatan Besi dan mentransformasikannya menjadi Perguruan Sumatra Thawallib, Haji Rasul, dan Ulama Kaum Mudo lainnya juga menyebarluaskan penggunaan buku bacaan sebagai sumber ilmu yang lebih penting, melakukan tablig akbar ke berbagai pelosok Minangkabau. Sementara Haji Abdullah Ahmad yang sebelumnya telah lama menjadi kontributor pada majalah Al-Imam (Singapura) yang peredarannya sampai ke Riau dan Minang, la juga mulai mendirikan surat kabar Islam pertama di Minang yakni Al-Moenir (1911-1916), dimana Haji Rasul terlibat sebagai pembantu redaksi di dalamnya. Ketika Al-Moenir ditutup karena kebakaran dan juga ancaman pelarangan dari pemerintah kolonial Hindia Belanda, Zainuddin Labai, yang merupakan alumni Surau Jembatan Besi, meneruskan penerbitan majalah Al-Moenir di Padang Panjang dengan nama Moeniroel Manar atau Al-Moenir Padang Panjang (19181922), yang didukung oleh Haji Rasul. ${ }^{41}$

Dari uraian di atas dapat diketahui posisi sentral dari Surau Jembatan Besi sampai menjadi Sumatra Thawalib dalam proses

40 Dt. R. Endah Hamidin, "Thawalib Padang Panjang dan Pembaharuan Pendidikan Islam," (Thesis, MA, Fakultas Pasca Sarjana, IAIN Syarif Hidayatullah Jakarta), 64-65.

${ }^{41}$ Gusti Asnan, "Pers Islam Di Sumatera Barat Pada Awal Abad XX: Suatu Gerakan Tinjauan Dalam pembaharuan di Minangkabau. Posisi tersebut tidak dapat dilepaskan dari kehadiran Haji Abdullah Ahmad dan Haji Rasul selaku pengelola, pengajar dan pemimpin di surau tersebut. Selain itu para murid atau jemaah dan alumni Surau Jembatan Besi juga turut terlibat dalam percepatan proses pembaharuan itu sendiri. Mereka adalah anak didik atau binaan Haji Rasul, yang kemudian diorganisir dan menjadi Perguruan Sumatra Thawalib. Fenomena-fenomena tersebut sejalan dengan karakteristik gerakan dakwah sebagaimana dibahas sebelumnya. Lebih konkret gerakan dakwah pembaharuan yang dilakukan melalui Surau Jembatan Besi sampai di masa awal Perguruan Sumatra Thawalib akan dibahas di bab selanjutnya.

\section{Gerakan Dakwah Pembaharuan Surau Jembatan Besi}

Haji Abdullah Ahmad dan Haji Rasul sebagai ulama pembaharu telah melakukan suatu gerakan dakwah pembaharuan di Minangkabau yang dimulai dari Surau Jembatan Besi Padang Panjang yang kemudian bertransformasi menjadi Perguruan Sumatra Thawalib. Dalam perspektif tersebut, Surau Jembatan Besi merupakan sebuah institusi yang menjalankan fungsi dakwah di masyarakat, dengan corak gerakan dakwah pembaharuan. Untuk itu dapat dianalisis latar belakang dan visi dakwah

Hubungannya DenganGerakan Pembaharuan". (Skripsi, Fakultas Sastra Universitas Andalas Padang, 1987), 45. 
pembaharuan yang dibawa, subjek-subjek dakwah yang terlibat dalam hal ini yang disebut sebagai Kaum Mudo, masyarakat yang menjadi mitra dakwah, pesan dakwah pembaharuan yang didengungkan, metode dan media dakwah yang digunakan, serta efek dari gerakan dakwah pembaharuan tersebut yaitu terkait reaksi para ulama yang disebut Kaum Tuo, golongan adat dan masyarakat Minangkabau pada umumnya.

\section{Latar Belakang dan Visi Dakwah Pembaharuan}

Kekhasan gerakan dakwah pembaharuan adalah selalu dilatarbelakangi adanya fenomena sosial kerusakan dan kemunduran umat Islam dalam berbagai bidang sebagai akibat tidak dilaksanakannnya ajaran Islam secara menyeluruh atau pelaksanaannya bertentangan dengan Alquran dan Sunah, itulah yang menjadi penyakit masyarakat. Oleh karenanya gerakan dakwah pembaharuan senantiasa menyerukan untuk kembali kepada Alquran dan Sunah, membuka pintu ijtihad dan mendorong pada kemajuan umat. Kerusakan akidah tauhid masyarakat Minangkabau nampak nyata dalam berbagai praktik ajaran Islam pada awal abad ke-20 M. Kebiasaan menggunakan azimat, memohon doa dan peruntungan di makam-makam yang dianggap keramat, praktik-praktik tarekat yang menyalahi ajaran Islam seperti memohon pertolongan Allah melalui perantara syekh atau guru tarekat, dan sebagainya adalah hal umum dan dipandang sebagai bagian dari ajaran Islam oleh masyarakat Minangkabau kala itu. Belum lagi persoalan adat kebiasaan yang bertentangan dengan Islam, seperti kebiasaan madat, sabung ayam, judi, hukum waris matrilineal, dan lain sebagainya yang itu diterima dan dianggap tidak bertentangan dengan Islam. Sehingga bercampuraduklah ajaran Islam itu dengan adat kebiasaan yang sebenarnya bertentangan dengan Islam dan menjadikannya mudah untuk dibodohi dan dijajah oleh bangsa asing. Keseluruhan fenomena itu mengindikasikan adanya penyakit kronis di masyarakat muslim Minangkabau, yang bersumber dari ketauhidan dan tidak dilaksanakannya Islam sesuai Alquran dan Sunah. Keadaan sosial inilah yang menjadi latar belakang kuat perlunya dilakukan pembaharuan melalui sebuah gerakan dakwah di masyarakat Minangkabau.

Gerakan dakwah yang dimaksudkan adalah yang menekankan aksi atau tindakan nyata, dengan pembentukan dan pembinaan jemaah, untuk selanjutnya diorganisir ke dalam sebuah kelompok pembaharu. Dalam kasus ini, gerakan dakwah pembaharuan yang dilakukan tidak membentuk suatu kelompok yang sama sekali baru, tetapi memanfaatkan pranata sosial yang sudah ada sebelumnya, yaitu surau. Gerakan dakwah pembaharuan tersebut juga dimungkinkan karena adanya pengaruh ideide pembaharuan yang dibawa oleh pemuda-pemuda Minangkabau setelah belajar di Mekkah dan mengalami kontak intelektual dengan ulama-ulama di Timur Tengah. Mereka adalah murid-murid Syekh Ahmad Khatib yang juga berasal dari Minangkabau, di antaranya Haji Abdullah Ahmad dan Haji Abdul Karim Amrullah atau Haji Rasul yang kemudian mengajar dan memimpin Surau Jembatan Besi dan menjadikannya pusat pembaharuan dengan kegiatan dakwah dan pendidikan. 
Dengan demikian latar belakang gerakan dakwah pembaharuan yang dilakukan oleh Haji Abdullah Ahmad dan Haji Rasul melalui Surau Jembatan Besi, dapat dibagi menjadi, pertama, latar belakang internal yaitu adanya realitas sosial kerusakan masyarakat Minangkabau yang tidak lagi sesuai dengan akidah tauhid, mencampuradukkan ajaran Islam dengan adat, kegiatan tarekat yang bertentangan dengan Islam, praktik taklid, bidah, dan khurafat yang sudah merajalela, serta keterbelakangan masyarakat muslim Minangkabau dari masyarakat Barat yang direpresentasikan dengan Pemerinatahan Kolonial Belanda yang menguasai sistem kehidupan masyarakat. Kedua, adalah latar belakang eksternal yaitu adanya pengaruh ide-ide pembaharuan dari Timur Tengah yang dibawa oleh pemuda-pemuda Minangkabau setelah belajar Islam di Mekkah. Di mana ide-ide pembaharuan tersebut juga menjadi gejala umum di beberapa kawasan Islam terutama di Timur Tengah. Di sisi lain guru mereka, yaitu Syekh Ahmad Khatib sendiri adalah seorang tokoh yang ketat dalam mengamalkan ajaran Islam dan menentang berbagai praktik dan adat Minangkabau yang tidak sesuai dengan Islam. Berdasarkan latar belakang tersebut, maka dapat dianalisis visi besar gerakan dakwah pembaharuan ini adalah untuk mengembalikan praktik ajaran Islam di Minangkabau agar sesuai Alquran dan Hadis. Secara spesifik visi gerakan dakwah pembaharuan ini dapat dikategorikan dalam tiga hal yaitu: (a) untuk memurnikan Tauhid dari praktik-praktik kesyirikan, bidah, takhayul dan tarekat yang tidak bersumber dari Islam; (b) menentang taklid buta terhadap ulama dan sebaliknya mendorong ijtihad atau menggunakan akal di segala bidang; dan (c) memajukan umat
Islam di berbagai bidang, melalui dakwah, pendidikan, dan sosial.

\section{Subjek dan Mitra Dakwah Pembaharuan}

Di atas telah disinggung bahwa pembaharuan Islam di Minangkabau pada awal abad ke-20 M dipelopori oleh ulamaulama muda, murid dari Syekh Ahmad Khatib. Mereka kemudian dikenal sebagai Kaum Mudo (Kaum Muda). Merekalah yang menjadi subjek utama dalam gerakan dakwah pembaharuan di Minangkabau. Istilah Kelompok atau Kaum Muda sebagai pendakwah dalam gerakan pembaharuan awalnya tidaklah identik dengan pendakwah dalam bentuk kelembagaan, tetapi sebagai suatu sebutan bagi ulamaulama muda yang memiliki kesamaan pemikiran dan gerakan untuk melakukan dakwah pembaharuan di masyarakat Minangkabau. Pelembagaan ulama-ulama pembaharu sebagai subjek dakwah sekaligus pendidikan Keislaman justru baru dimulai dengan disepakatinya organisasi Sumatra Thawalib, yang selanjutnya lebih berkembang menjadi suatu institusi pendidikan Islam yang modern.

Kaum Mudo pula yang menjadi penggerak utama dalam dakwah pembaharuan melalui Surau Jembatan Besi, yaitu oleh Haji Abdullah Ahmad dan Haji Abdul Karim Amrullah. Mereka membina para murid dan jemaah Surau Jembatan Besi dengan gagasan-gagasan pembaharuan Islam. Lantas para murid dan jemaah tersebut turut pula dalam penyebarluasan gagasangagasan pembaharuan. Para murid-murid yang telah menyelesaikan pendidikan keagamaannya di Surau Jembatan Besi terlibat sebagai tenaga pengajar sekaligus pendakwah, baik di Surau Jembatan Besi 
maupun di surau kampung halamannya. Sebagian alumni juga terlibat dalam kegiatan penerbitan surat kabar Al-Moenir di Padang Panjang, sebagai media tulis yang membawa ide-ide pembaharuan Islam di masyarakat Minangkabau. Para alumni dan guru Surau Jembatan Besi itulah yang kemudian diorganisir, yang dalam perkembangan menjadi Sumatra Thawalib. Pola yang semacam itu sejalan dengan karakteristik dalam konsep gerakan dakwah, subjek yang terlibat dalam dakwah gerakan bukanlah individu-individu yang berdiri sendiri, melainkan sebuah kelompok, dalam hal ini adalah dimulai dari Surau Jembatan Besi. Kelompok tersebut dibentuk, dibina dan dididik, serta diorganisasikan menjadi suatu gerakan dengan identitas dan visi yang kuat. Sehingga dari yang semula menjadi mitra dakwah kemudian ikut, terlibat menjadi subjek dakwah. Ciri ini bisa ditemukan dalam fenomena subjek dakwah Surau Jembatan Besi. Perbedaannya, kelompok yang dibangun tidaklah membentuk kelompok baru, melainkan menggunakan pranata sosial yang ada dan cukup mapan keberadaannya di masyarakat, yaitu surau. Murid dan jemaah surau itulah yang menjadi mitra dakwah pemabaharuan awal, yang kemudian dibina, dididik, dan diorganisir, sehingga merekapun kemudian menjadi subjek dakwah. Dengan demikian bisa disimpulkan bahwa subjek gerakan dakwah pembaharuan Surau Jembatan Besi, dipelopori oleh duo ulama pembaharu Kaum Mudo, Haji Abdullah Ahmad dan Haji Abdul Karim Amrullah, yang diikuti dengan para guru, alumni, murid dan jemaah Surau Jembatan Besi, yang selanjutnya terlembagakan dalam Perguruan Sumatra Thawalib Padang Panjang. Saat itulah subjek dakwah dalam gerakan pembaharuan menjadi terlembagakan.

Sementara mitra dakwah yang menjadi sasaran gerakan dakwah pembaharuan adalah masyarakat Minangkabau yang mayoritasnya adalah beragama Islam. Hal tersebut sejalan dengan latar belakang masalah dan tujuan gerakan dakwah pembaharuan yang dilakukan dalam Surau Jembatan Besi. Di mana gerakan dakwah pembaharuan ini dilakukan karena adanya fenomena kerusakan akidah tauhid dan berbagai penyakit sosial yang melanda masyarakat Minangkabau. Masyarakat Minangkabau yang menjadi sasaran gerakan dakwah pembaharuan Surau Jembatan Besi atau Sumatra Thawalib dapat dibedakan menjadi dua jenis, yaitu, pertama, murid-murid dan jemaah yang mengaji di Surau Jembatan Besi atau Perguruan Sumatra Thawalib Padang Panjang. Mereka inilah yang dibina dan diorganisir, serta diharapkan untuk menjadi kader-kader dakwah pembaharuan selanjutnya. Kedua, masyarakat muslim Minangkabau secara umum, yang diharapkan untuk menerima pesan dakwah pembaharuan dan menjalankannnya dalam kehidupan sehari-hari. Mitra dakwah yang kedua ini dapat diklasifikasi menjadi tiga kelompok, yaitu: (a) golongan adat, yaitu ketua atau pemangku adat di setiap nagari (pembagaian wilayah Minangkabau), penghulu, dan para ninik-mamak; (b) golongan ulama yang berupaya mempertahankan tradisi dan menentang pembaharuan, yang disebut Kaum Tuo; (c) golongan masyarakat awam, yaitu mereka yang tidak masuk kelompok adat maupun ulama Kaum Tuo. Terhadap berbagai mitra dakwahnya, para ulama pembaharu dari Surau Jembatan Besi memberikan 
perlakuan dakwah yang berbeda, khususnya dari segi metode dan media dakwah pembaharuan yang digunakan. Adapun pesan dakwah yang disebarluaskan kepada berbagai jenis mitra dakwah, secara substansi adalah sama.

\section{Pesan Dakwah Pembaharuan Bidang}

\section{Adat, Tarekat, dan Syariat}

Pesan dalam dakwah pembaharuan terkait ide, gagasan, dan pemikiran baru atau berbeda bahkan bertentangan dengan yang sudah ada, yang kemudian dijual atau sebarluaskan ke mitra dakwah. Dalam konteks gerakan dakwah pembaharuan, pesan-pesan dakwah yang dimunculkan selalu dikaitkan dengan latar belakang persoalan penyakit masyarakat mitra dakwah yang menjadi sasaran. Penyakit masyarakat yang menjadi latar belakang gerakan dakwah pembaharuan dari Surau Jembatan Besi sampai Sumatra Thawalib adalah terkait akidah Ketauhidan yang bercampur dengan adat dan ajaran tarekat yang tidak sesuai dengan Islam, serta praktik-praktik syariat yang menyimpang. Untuk itu pesan dalam gerakan dakwah pembaharuan Surau Jembatan Besi dapat diklasifikasi dalam tiga bidang sasaran pembaharuan, yaitu masalah adat, tarekat, dan syariat.

\section{a. Pesan Dakwah Pembaharuan Bidang}

\section{Adat}

Telah dijelaskan sebelumnya bahwa para ulama pembaharu menilai ada banyak bagian dari adat Minangkabau yang bertentangan dengan ajaran Islam. Atas dasar itulah mereka memberikan gagasan pembaharuan yang menjadi pesan dakwah dalam bidang adat. Sumber-sumber yang menjadi rujukan pesan dakwahnya, selain Alquran dan Sunah adalah fatwa-fatwa dari ulama dan guru mereka, Syekh Ahmad Khatib Al-Minangkbaui. Dalam masalah adat, sikap Haji Abdullah Ahmad dan Haji Rasul memang tidaklah sekeras sikap Syekh Ahmad Khatib yang menolak dengan keras adat. Begitu pula para murid dan jemaah Surau Jembatan Besi dan Sumatra Thawalib. Mereka masih menghargai dan tetap memakai adat yang baik yang tidak bertentangan Islam. Artinya pesan-pesan dakwah pembaharuan mereka tidak menyarankan untuk mengganti keseluruhan adat Minangkabau, tetapi adat-adat yang bertentangan dengan ajaran Islam itulah yang menjadi sasaran pesan dakwah pembaharuan.

Beberapa pesan dakwah pembaharuan bidang adat di antaranya adalah: ${ }^{42}$ (1) masalah hukum waris, dalam adat minang warisan bersifat matrilineal sehingga diganti dengan hukum waris Islam, serta menentang dan menghilangkan adat mewariskan harta pusaka kepada kemenakan; (2) masalah perjodohan dan perkawinan. Menurut adat, jodoh ditentukan dan dipilihkan oleh ninikmamak, dan praktik perkawinan selama ini dilaksanakan menurut adat dan penghulu. Terdapat juga adat nikah muda untuk perempuan, yang secara tidak langsung menghalangi kemajuan ilmu dan agama di kalangan perempuan. Pesan dakwah pembaharuan yang disampaikan terkait kebebasan memilih jodoh, pelaksanaan perkawinan sesuai dengan hukum Islam, serta menyampaikan bahwa perempuan tidak harus nikah muda, mereka boleh bahkan harus untuk menuntut ilmu; (3)

\footnotetext{
42 Daya, Gerakan Pembaharuan., 163-175.
} 
masalah kepercayaan tradisional atau paham animisme dan dinamisme, seperti kepercayaan kepada kekuatan arwah, mandi safar, melakukan kenduri arwah pada malam-malam tertentu, kepercayaan terhadap azimat, dan sebagainya. Pesan dakwah pembaharuan yang disampaikan terkait ketauhidan dalam Islam, mendudukkan masalah arwah, dan azimat dalam Islam; (4) masalah kebiasaan negatif yang sudah melembaga, seperti judi, sambung ayam, menghisap madat, dan sejenisnya. Pesan dakwah pembaharuan yang disampaikan secara tegas menolak dan menentang kebiasaan-kebiasaan tersebut dan menyatakannya sebagai kebiasaan jahiliyah yang harus ditinggalkan umat Islam.

\section{b. Pesan Dakwah Pembaharuan Bidang Tarekat}

Tarekat telah menjadi kesenangan dan kebanggaan masyarakat Minangkabau, utamanya dari syekh atau ulama-ulama yang disebut sebagai Kaum Tuo. Mereka meyakini kalau tarekat berasal dari Nabi Muhammad, sehingga mengingkarinya berarti mengingkari Nabi Muhammad. Dalam pandangan mereka, tarekat adalah bagian dari ajaran Islam dan Nabi memerintahkan untuk memasukinya, karena tarekat adalah tiang bagi orang yang menuju jalan Allah. Ada beberapa hadis dan ayat Alquran yang dijadikan dasar bagi mereka untuk melaksanakan dan mengembangkan ajaran tarekat. Tercatat tarekat Satariah dan Naksabandiah merupakan tarekat yang besar dan berpengaruh di masyarakat Minangkabau. ${ }^{43}$ Selain itu para syekh-syekh tarekat memiliki kesamaan yang umum, seperti pembelaan

43 Ibid., 179-181.

${ }^{44}$ Ibid., 192-193. terhadap adat, menjalankan ibadah suluk dengan rabitah, mengharamkan pakaian orang Eropa, meniga hari, menujuh hari, empat puluh hari, dan menyeratuskan hari mayat dianggap sebagai amalan dari Nabi, wajib taklid, percaya kepada kesaktian rohroh halus, kesaktian dukun, tukang tenun, orang-orang keramat, dan sebagainya. ${ }^{44}$

Pemikiran-pemikiran itulah yang hendak dilawan dan diperbaharui. Sebab dalam kacamata Haji Abdullah Ahmad dan Haji Rasul, juga para ulama Kaum Mudo lainnya, amalan-amalan tersebut (tarekat dan segala turunannya) adalah amalan yang ganjil dan dipertanyakan keabsahannya, sehingga terjadilah perselisihan antara penganut tarekat dengan yang bukan menjadi anggota tarekat. Untuk itu dimintakanlah fatwa kepada guru mereka Syekh Ahmad Khatib terkait kebenaran ajaran tarekat, yang kemudian ditulis dalam buku berjudul Izhharu Zaghli al-Khadhibin fi Tasyabbuhihim bi al-Shadiqin, yang pada intinya dijelaskan bahwa tarekat tidak berasal dari Nabi maupun sahabat, silsilah guru tarekat yang sampai kepada Nabi adalah palsu, ajaran amalan suluk dan rabitah adalah bidah dan tidak berasal dari Nabi. ${ }^{45}$ Fatwa dari guru mereka inilah yang menjadi poin penting pesan dakwah dalam upaya memperbaharui pemikiran tentang tarekat. Haji Rasul juga melancarkan pesan dakwah yang keras untuk mengkritik tarekat. Mula-mula yang difatwakan adalah bahwa merabitahkan guru dalam suluk bukan berasal dari syariat Islam. Berbagai amalan seperti berkhalwat dengan zikir sampai berpuluh atau beratus hari, pantang makan daging dengan niat ibadah, membaca zikir dengan batu, zikir Allah-Allah

45 Ibid., 194. 
dan Huwa'llah Huwa'llah adalah bidah, melanggar hukum Islam sejati. Demikian pula meminta pertolongan kepada orangorang keramat dan kepada rabitah (rupa guru) yang dihadirkan tatkala zikir dan doa agar sampai kepada Tuhan adalah sebuah kesyirikan. ${ }^{46}$ Secara keseluruhan ulama pembaharu dari Surau Jembatan Besi sampai Perguruan Sumatra Thawalib menolak tarekat. Dan dengan tegas menyampaikan pesan dakwah bahwa tarekat tidak berasal dari nabi, maka ia bidah. ajaran-ajaran dan amalan-amalan yang dikembangkannya bersifat khurafat dan bercampur dengan takhayul yang ditentang oleh Islam.

\section{c. Pesan Dakwah Pembaruan Bidang}

\section{Syariat}

Masalah dalam bidang syariat yang terjadi di masyarakat Minangkabau pada hakikatnya adalah imbas dari permasalahan tarekat dan adat. Suburnya tarekat dan adat yang bertentangan dengan Islam, mengakibatkan masyarakat tidak melaksanakan ajaran Islam sebagaimana yang disyariatkan. Sebab masalah dalam bidang tarekat dan adat berimbas pada masalah akidah ketauhidan umat Islam. Umat Islam Minangkabau banyak sekali mengamalkan ajaran-ajaran yang tidak jelas sumbernya atau tidak ada dasarnya dalam Alquran dan Hadis. Untuk itu pesan dakwah dalam bidang syariat juga menjadi masalah yang perlu diselesaikan dalam upaya pembaharuan.

Dalam hal ini, Haji Rasul sangat menganjurkan umat Islam untuk tidak taklid pada ulama atau hanya pada satu mazhab saja dan mendorong untuk dilakukannya

${ }^{46}$ Ibid., 194. ijtihad. Demikian pula yang ia lakukan dalam menyelesaikan masalah-masalah umat. Dia berusaha memahami persoalan secara luas dan mendalam, dalam masalah hukum bukan hanya membandingkan pemikiran empat imam mazhab, tetapi juga dengan pendapat mazhab lainnya, sebelum dia mengambil keputusan sendiri. Berbagai masalah keumatan, seperti hukum talak tiga yang dijatuhkan sekaligus, masalah nikah muhil, tentang shalat id apakah di masjid atau di lapangan? Kebolehan wanita mengikuti salat id, masalah penggunaan hisab untuk penentuan awal puasa dan hari raya, dan sebagainya. Semua masalah itu ia telaah secara mendalam, menggunakan rujukan berbagai mazhab, menghubungkannya dengan hadis dan nash Alquran, baru kemudian disimpulkan. Pada prinsipnya Haji Rasul mewajibkan supaya umat muslim berpedoman kepada Alquran dan Hadis Shahih, tidak boleh bertaklid, karena taklid adalah derajat yang paling rendah. ${ }^{47}$ Pesan dakwah yang serba baru tersebut, diikuti oleh terutama muridmuridnya di Surau Jembatan Besi, yang kemudian terlibat dalam penyampaian pesan-pesan dakwah pembaharuan lebih luas lagi ke masyarakat.

\section{Metode dan Media Dakwah yang Digunakan}

Di atas telah dijelaskan siapa-siapa saja yang menjadi mitra dakwah sasaran dakwah pembaharuan ulama pembaharu dalam Surau Jembatan Besi, yaitu ada dari para murid dan jemaah Surau Jembatan Besi dan Perguruan Sumatra Thawalib; masyarakat awam Minangkabau pada umumnya; Ulama Kaum Tuo; dan para pemangku adat

\footnotetext{
47 Ibid., 204, 209, 211-212.
} 
Minangkabau. Para murid dan jemaah adalah mitra dakwah yang diharapkan menjadi kader-kader pembaharu dan turut pula dalam gerakan dakwah pembaharuan, sedangkan masyarakat awam, pemangku adat dan Ulama Kaum Tuo diharapkan dapat mengetahui dan menerima pesanpesan dakwah pembaharuan, baik dalam bidang adat, tarekat maupun syariat.

Metode-metode dakwah yang dilancarkan antara lain seperti menulis buku, mengadakan perdebatan-perdebatan, tablig, ceramah-ceramah agama dan juga dengan langsung memberantas amalan tarekat dan adat yang bertentangan dengan Islam. Kebiasaan membaca kitab riwayat Isra Mikraj Nabi dengan menerjemahkannya dari bahasa Arab, diganti dengan tablig akbar dan diceritakan dalam bahasa Melayu. Tradisi membaca kitab, diganti dengan membahas problem hidup sehari-hari, dan pengajian tafsir. Dengan cara ini, maka dapat diberantaslah semua bidah, khurafat, dongeng-dongeng dan kepercayaan-kepercayaan yang menyesatkan, serta dilaksanakan amar makruf nahi mungkar. ${ }^{48}$ Praktik metode dakwah melalui tablig akbar, forum-forum perdebatan, dan pengajaran yang berjenjang merupakan metode-metode baru yang tidak pernah atau tidak biasa diterapkan dalam dakwah Islam di masyarakat Minangkabau kala itu. Sebab aktivitas dakwah dan keagamaan umumnya dilakukan melalui sistem tarekat dengan banyak praktik yang menyimpang. Adapun metode dan media dakwah yang digunakan para pendakwah pembaharu Surau Jembatan Besi dan Perguruan Sumatra Thawalib dapat disusun dalam tabel berikut:

Tabel 1 - Metode dan Media Dakwah dalam Gerakan Dakwah Pembaharuan Surau Jembatan Besi

\begin{tabular}{|c|c|c|c|}
\hline Mitra Dakwah & Target & Metode Dakwah & Media Dakwah \\
\hline $\begin{array}{l}\text { Murid dan Jemaah } \\
\text { Surau Jembatan Besi } \\
\text { dan Perguruan Sumatra }\end{array}$ & $\begin{array}{l}\text { Kader Inti } \\
\text { Pergerakan } \\
\text { Pembaharuan }\end{array}$ & $\begin{array}{lr}\text { - Pengajaran secara } \\
\text { langsung, dengan sistem } \\
\text { berjenjang }\end{array}$ & $\begin{array}{l}\text { - Penyampaian lisan } \\
\text { - Tulisan (karya tulis } \\
\text { [buku, artikel] Haji }\end{array}$ \\
\hline $\begin{array}{l}\text { Thawalib Padang } \\
\text { Panjang }\end{array}$ & & $\begin{array}{l}\text { terkurikulum } \\
\text { - Contoh/keteladanan dari } \\
\text { pimpinan (Haji Rasul) } \\
\text { dan guru-guru senior } \\
\text { lainnya }\end{array}$ & $\begin{array}{l}\text { Rasul, Abdullah } \\
\text { Ahmad, Zainudin } \\
\text { Labai, dan sebagainya) } \\
\text { - Aktivitas keseharian } \\
\text { dan pemecahan } \\
\text { masalah keumatan }\end{array}$ \\
\hline
\end{tabular}

48 Ibid., 197-202. 


\begin{tabular}{|c|c|c|c|}
\hline Mitra Dakwah & Target & Metode Dakwah & Media Dakwah \\
\hline $\begin{array}{l}\text { Kelompok Adat (Para } \\
\text { Penghulu, } \\
\text { Mamak, Ketua Adat) } \\
\text { yang juga beragama } \\
\text { Islam }\end{array}$ & $\begin{array}{l}\text { Menerima } \\
\text { pesan dakwah } \\
\text { pembaharuan } \\
\text { bidang adat }\end{array}$ & $\begin{array}{l}\text { - Tablig akbar atau } \\
\text { ceramah keagamaan } \\
\text { masalah adat } \\
\text { - Melalui tulisan } \\
\text { - Melalui } \\
\text { tindakan/perbuatan } \\
\text { untuk menolak adat yang } \\
\text { dipandang bertentangan } \\
\text { dengan Islam }\end{array}$ & $\begin{array}{l}\text { - Penyampaian lisan } \\
\text { - Tulisan (buku, artikel, } \\
\text { surat kabar Al-Moenir } \\
\text { dan Al-Moenir Padang } \\
\text { Panjang) } \\
\text { - Aktivitas tertentu } \\
\text { menolak adat (seperti } \\
\text { menolak dijodohkan } \\
\text { ninik-mamak, } \\
\text { melakukan hukum } \\
\text { waris sesuai Islam, dan } \\
\text { lain-lain) }\end{array}$ \\
\hline $\begin{array}{l}\text { Kelompok Ulama Kaum } \\
\text { Tuo (Pemimpin atau } \\
\text { Syekh Tarekat, Ulama } \\
\text { Tradisional) }\end{array}$ & $\begin{array}{l}\text { Menerima } \\
\text { pesan dakwah } \\
\text { pembaharuan } \\
\text { bidang tarekat } \\
\text { dan syariat }\end{array}$ & $\begin{array}{l}\text { - Perdebatan pemikiran } \\
\text { - Menggunakan fatwa dari } \\
\text { ulama yang dipandang } \\
\text { lebih ahli (Syekh Ahmad } \\
\text { Khatib) }\end{array}$ & $\begin{array}{l}\text { - Penyampaian lisan } \\
\text { - Tulisan (buku, artikel, } \\
\text { surat kabar) }\end{array}$ \\
\hline $\begin{array}{l}\text { Masyarakat awam } \\
\text { Minangkabau }\end{array}$ & $\begin{array}{l}\text { Menerima } \\
\text { seluruh pesan- } \\
\text { pesan dakwah } \\
\text { pembaharuan }\end{array}$ & $\begin{array}{l}\text { - Tablig akbar atau } \\
\text { ceramah keagamaan } \\
\text { - Melalui tulisan }\end{array}$ & $\begin{array}{l}\text { - Penyampaian lisan } \\
\text { - Buku, artikel (karya } \\
\text { Haji Rasul, Abdullah } \\
\text { Ahmad, Zainuddin } \\
\text { Labai, dan sebagainya) } \\
\text { - Surat kabar Al-Moenir } \\
\text { dan Al-Moenir Padang } \\
\text { Panjang }\end{array}$ \\
\hline
\end{tabular}

\section{Efek Gerakan Dakwah Pembaharuan} Salah satu ciri gerakan dakwah pembaharuan dalam efek dakwahnya adalah adanya mereka yang pro dan kontra terhadap gagasan pesan dakwah yang dibawa. Demikian pula dalam fenomena gerakan dakwah pembaharuan dari Surau Jembatan Besi sampai Perguruan Sumatra Thawalib Padang Panjang, terdapat mitra dakwah yang setuju dan yang menolak terhadap gagasan pesan dakwah pembaharuan di bidang adat, tarekat, dan syariat. Penerimaan utamanya datang dari para murid dan jemaah Surau Jembatan Besi dan Sumatra Thawalib Padang Panjang. Penolakan datang dari dua kelompok mitra dakwah yaitu Kaum Adat dan Ulama Kaum Tuo. Namun penolakan yang paling keras adalah dari Kaum Tuo. Semantara bagi kaum adat, lambat laun terjadi penyesuaian-penyesuaian, sebab dalam adat Minangkabau sendiri memiliki semboyan "usang-usang diperbaharui," yang berarti terbuka menerima perubahan. Sementara para ulama pembaharu Surau Jembatan Besi juga tetap menghargai dan memakai adat yang baik yang tidak bertentangan dengan Islam. Hal ini terihat dengan adanya usaha membentuk satu organisasi yang diberi nama Persatuan Kebangsaan Minangkabau. Tujuannya adalah untuk memelihara, menghargai, dan mencintai adat yang baik, memelihara serta mengusahakan agar seluruh putra putri Minangkabau mencintai dan menghargai agama Islam, memajukan pendidikan, 
pengajaran, pertukaran serta memelihara harta kekayaan Minangkabau termasuk adatnya yang bernilai baik sesuai dengan ajaran agama Islam. ${ }^{49}$

Penolakan keras dari Ulama Kaum Tuo, karena Kaum Mudo Surau Jembatan Besi dan Sumatra Thawalib menyampaikan pesan dakwah untuk menolak tarekat dan segala bentuk praktik yang dianggapnya menyimpang dan bidah, serta mendorong untuk tidak taklid. Menggoncang aspek tersebut, bagi Kaum Tuo tidak hanya menggoncang keyakinan mereka saja, tetapi juga status sosialnya di masyarakat Minangkabau. Untuk itu perdebatanperdebatan keras terjadi antara Kaum Mudo dan Kaum Tuo, baik itu secara langsung dalam forum-forum yang ditujukan untuk itu, maupun melalui karyakarya tulis, berupa buku, artikel, dalam surat kabar, dan sebagainya. Perdebatanperdebatan tersebut menyajikan suatu dialektika intelektual, yang walaupun tidak selalu menemukan titik temu, tetapi publik atau masyarakat Minangkabau pada umumnya menjadi lebih bertambah wawasan dan pengetahuannya, yang akhirnya menjadi bekal bagi mereka untuk menilai apakah mengikuti gagasan pembaharuan Kaum Mudo ataukah bertahan dengan Kaum Tuo. Walhasil secara keseluruhan efek gerakan dakwah pembaharuan yang salah satunya dipelopori Surau Jembatan Besi dan Perguruan Sumatra Thawalib Padang Panjang memberikan efek perubahan corak dan praktik Keislaman di Minangkabau. Beberapa hukum adat juga mengalami penyesuaian-penyesuaian agar tidak bertentangan dengan ajaran Islam. Corak tarekat dengan segala praktiknya yang bertentangan dengan Alquran dan Hadis tidak lagi menjadi corak umum masyarakat muslim Minangkabau, sekalipun tidak lenyap sama sekali.

\section{Kesimpulan}

Surau Jembatan besi yang sebelumnya adalah sebagaimana surau tradisional pada umumnya telah berubah menjadi pusat pergerakan dakwah pembaharuan, yang selanjutnya bertransformasi menjadi Perguruan Sumatra Thawalib Padang Panjang. Secara keseluruhan fenomena gerakan dakwah pembaharuan Kaum Mudo dari Surau Jembatan Besi memiliki karakteristik khas gerakan dakwah pembaharuan pada umumnya. Perbedaannya terletak pada pemanfaatan pranata sosial yang sudah ada di masyarakat sebagai basis pembentukan pergerakan, dalam hal ini adalah surau. Kekhasan karakteristik tersebut diindikasikan, pertama, dari latar belakang dan visi dakwah pembaharuannya yang berangkat dari masalah sosial atau penyakit masyarakat muslim Minangkabau, yaitu terkait masalah adat yang bertentangan dengan Islam, ajaran tarekat dan berbagai praktik pelaksanaannya yang sudah menyimpang dari Alquran dan Sunah, serta berbagai praktik syariat keagamaan yang mencampuradukkan dengan adat, kepercayaan takhayul, dan sikap taklid. Untuk itulah visi dakwah pembaharuan diarahkan agar umat Islam Minangkabau kembali kepada Alquran dan Sunah, mempraktikkan ajaran Islam secara murni dan kaffah, menghilangkan kepercayaankepercayaan takhayul, berbagai praktik

${ }^{49}$ Ibid., 176-177. 
bidah dan khurafat, baik dalam masalah adat, tarekat, maupun syariat.

Kedua, hubungan antara subjek dan mitra dakwah utama yaitu murid dan jemaah Surau Jembatan Besi, berpola sebagaimana kaderisasi pergerakan dakwah. Artinya mitra dakwah tidak hanya didakwahi, tetapi juga dibina, dan diorganisir agar selanjutnya turut terlibat dalam gerakan-gerakan dakwah pembaharuan yang dilakukan. Ketiga, pesan dakwah yang dibawa sejalan dengan persoalan-persoalan yang menjadi penyakit masyarakat Minangkabau, yaitu masalah adat, tarekat, dan syariat. Keempat, secara metode dan media dakwah yang digunakan tidak terpaku pada pola-pola yang sudah ada, tetapi memunculkan cara-cara dan media baru dalam upaya dakwah pembaharuan, seperti mengadakan tablig akbar, dakwah melalui media surat kabar Al-Moenir, dan dakwah melalui perdebatan-perdebatan di forum atau melalui tulisan. Kelima, gerakan dakwah pembaharuan yang dilakukan menimbulkan pro dan kontra di kalangan masyarakat mitra dakwah, dalam hal ini utamanya adalah dari Ulama Kaum Tuo. Sungguhpun demikian gerakan dakwah pembaharuan melalui Surau Jembatan besi dan Perguruan Sumatra Thawalib Padang Panjang menunjukkan hasil yang lebih nyata adanya penerimaan dan pelaksanaan pesan-pesan dakwah dalam masalah adat, tarekat, dan syariat.

Hasil dari studi ini menunjukkan bahwa gerakan dakwah pembaharuan sekalipun bersifat fundamental tidak harus dilakukan dengan cara-cara pemaksaan dan kekerasan. Gerakan dakwah dari Surau Jembatan Besi sampai Perguruan Sumatra Thawalib Padang Panjang dalam melakukan pembaharuan di masyarakat Minangkabau justru tanpa melakukan pemaksaan dan kekerasan, tetapi lebih menekankan melalui dialektika pemikiran, baik dilakukan melalui pengajian dan pengajaran di surau, perdebatan-perdebatan dengan Kaum Adat dan Ulama Kaum Tuo, memberikan penerangan melalui media massa, penulisan buku, dan sebagainya. Mereka juga tidak terpaku pada metode dan media dakwah yang telah ada di masyarakat sebelumnya, tetapi dikembangkan sesuai dengan kebutuhan. Hal tersebut sejalan dengan corak kemajuan dan rasionalitas yang mereka bawa, yang diyakini pula sebagai perintah Alquran dan Sunah. Dalam konteks dakwah hari ini, dimana proses dakwah pembaharuan masih perlu terus dilakukan, mengingat belum sepenuhnya masyarakat Islam Indonesia meninggalkan praktik-praktik ajaran Islam yang menyimpang, maka gerakan dakwah pembaharuan perlu dilakukan dengan caracara yang sejalan dengan corak kemajuan dan rasionalitas. Artinya aktivis dakwah tidak boleh hanya terpaku pada cara-cara dakwah lama, seperti kehadiran media baru akibat perkembangan teknologi mesti perlu diterima dan dijadikan peluang untuk pengembangan dakwah. Dialektika pemikiran itulah yang perlu dihidupkan tanpa perlu melakukan pemaksaan maupun kekerasan. Dengan begitu, dakwah pembaharuan Islam akan lebih mudah diterima masyarakat, sejalan dengan perkembangan modernitas masyarakat. 


\section{Bibliografi}

Abdullah, Taufik. School and Politics, The Kaum Muda Movement in West Sumatra 1927-1933. New York: Cornell University, 1971.

Ali, A. Mukti. Alam Pikiran Modern di Indonesia. Yogyakarta: Yayasan Nida, 1971.

Asnan, Gusti. "Pers Islam Di Sumatra Barat Pada Awal Abad XX: Suatu Gerakan Tinjauan Dalam Hubungannya Dengan Gerakan Pembaharuan." Skripsi, Fakultas Sastra Universitas Andalas Padang, 1987.

Aziz, M. Ali. Ilmu Dakwah Edisi Revisi. Jakarta: Prenadamedia Grup, 2016.

Azra, Azyumardi. "Surau di Tengah Krisis: Pesantren dalam Perspektif Masyarakat" dalam Rahardjo, Dawam. Pergulatan Dunia Pesantren Membangun dari Bawah. Jakarta: P2M, 1985.

Daya, Burhanuddin. Gerakan Pembaruan Pemikiran Islam: Kasus Sumatra Thawalib. Yogyakarta: Tiara Wacana, 1990.

Departemen Pendidikan Nasional. Kamus Besar Bahasa Indonesia. Jakarta: Balai Pustaka, 2005. Hamidin, Dt. R. Endah. "Thawalib Padang Panjang dan Pembaharuan Pendidikan Islam." Thesis, MA, Fakultas Pasca Sarjana, IAIN Syarif Hidayatullah Jakarta.

Hamka. Ayahku. Jakarta: Uminda, 1982. . Islam dan Adat Minangkabau. Jakarta: Pustaka Panjimas, 1985.

Ismail, A. llyas dan Hotman, Prio. Filsafat Dakwah Rekayasa Membangun Agama dan Peradaban Islam. Jakarta: Kencana, 2011.

Muhiddin, Asep. Dakwah dalam Perspektif Al-Quran. Bandung: Pustaka Setia, 2002.

Nasution, Harun. Pembaharuan Dalam Islam Sejarah Pemikiran dan Gerakan. Jakarta: Bulan Bintang, 1992.

Nawawi, Ismail. Metode Penelitian Kualitatif. Jakarta: Dwiputra Pustaka, 2012.

Nizar, Samsul. Memperbincangkan Dinamika Intelektual dan Pemikiran Hamka Tentang Pemikiran Islam. Jakarta: Kencana, 2007.

Noer, Deliar. Gerakan Modern Islam di Indonesia 1900-1942. Jakarta: LP3ES, 1996.

Rahman, Rini. "Modernisasi Pendidikan Islam Awal Abad 20 Studi Kasus di Sumatra Barat." Jurnal Humanus, Volume XIV Nomor 02 (2015).

Saerozi, Muh. "Model of Strategies in Developing Islamic Thought Through Curriculum: A Study of Sumatra Thawalib 1900-1942," Indonesian Journal of Islam and Muslim Societies (IIIMS) Volume 4, Number 2, (December 2014).

Syamsuddin, Fachri. "Pembaharuan Islam di Minangkabau Awal Abad XX: Studi terhadap Pemikiran Syekh Muhammad Jamil Jambek, Syekh Abdullah Ahmad, dan Syekh Abdul Karim Amrullah." Disertasi, IAIN Sunan Kalijaga, Yogyakarta, 2004.

Zumrotin. "Modernisme Islam dan Implikasinya terhadap Kehidupan Politik Umat Islam di Indonesia pada Paruh Pertama Abad ke-XX M." Skripsi, IAIN Sunan Ampel, Surabaya, 1996. 
Dedy Pradesa, Siti Umayatun, M. Abdul Aziz 